\title{
INVESTIGATION OF THE FREEZE-THAW RESISTANCE OF ECO-POROUS CONCRETE CONTAINING FLY ASH
}

\author{
PREISKAVE ODPORNOSTI NA ZAMRZOVANJE IN ODTALJE- \\ VANJE EKOPOROZNIH BETONOV, KI VSEBUJEJO PEPEL
}

\author{
Gui Zhang, Jian Yin, Sheng Li, Zhenghui Sang, Yao Xiong, Ting Gao, Xiongwei Hu \\ College of Civil Engineering, Central South University of Forestry and Technology, Changsha 410018, China \\ 1002919857@qq.com
}

Prejem rokopisa - received: 2017-06-15; sprejem za objavo - accepted for publication: 2017-07-28

doi:10.17222/mit.2017.073

\begin{abstract}
Laboratory tests were conducted to evaluate the freeze-thaw resistance of eco-porous concrete containing fly ash. In order to address the freeze-thaw resistance of eco-porous concrete, the mass loss, compressive strength and relative dynamic modulus of elasticity (RDME) were obtained. Furthermore, based on the RDME, the freeze-thaw damage index (FTI) was provided to evaluate the internal damage. The results showed that the higher the amount of fly ash, the poorer is the frost resistance of porous concrete. The mass, compressive strength and RDME of specimens decreased with the increasing freeze-thaw cycles. The compressive strength decreased with an increase in fly ash, but the initial compressive strength is sufficient for requirements. Therefore, the content of fly ash should be controlled when producing eco-porous concrete and predicting its
\end{abstract} performance under freeze-thaw attacks with the explored method.

Keywords: eco-porous concrete, fly ash, freeze-thaw resistance, mass loss, relative dynamic modulus of elasticity (RDME), freeze-thaw damage index (FTI)

Avtorji prispevka so z laboratorijskimi preizkusi ugotavljali odpornost na zamrzovanje in odtaljevanje (FTR, angl.: Freeze-Thaw Resistance), s pepelom polnjenih ekoporoznih betonov. Da bi dobili podatke o odpornosti betona so določevali izgubo mase, tlačno trdnost in relativni dinamični modul elastičnosti (RDME). Na podlagi RDME so določili indeks poškodb med preizkusom zamrzovanja in odtaljevanja (FTI, angl.: Freeze-Thaw Damage index), ki je merilo notranjih poškodb betona po izvedenem preizkusu. Rezultati so pokazali, da večja kot je polnitev poroznega betona z elektrofiltrskim pepelom, slabša je njegova odpornost na zamrzovanje. Masa, tlačna trdnost in RDME preizkušancev so se zmanjševali z naraščajočim številom ciklov zamrzovanja in odtaljevanja. Tlačna trdnost poroznega betona se je precej zmanjšala $s$ povečevanjem deleža elektrofiltrskega pepela, kljub temu, da so bile vrednosti začetne tlačne trdnosti betona znotraj predpisov. Zato je potrebno delež elektrofiltrskega pepela nadzorovati, ko se oblikuje nove, s pepelom polnjene, ekološke porozne betone in jih testirati oz. ovrednotiti $\mathrm{z}, \mathrm{v}$ tem članku opisano, metodo zamrzovanja in odtaljevanja.

Ključne besede: ekoporozni beton, elektrofiltrski pepel, odpornost na zamrzovanje in odtaljevanje, izguba mase, relativni dinamični modul elastičnosti (RDME), indeks poškodb betona nastalih med preizkusom zamrzovanja in odtaljevanja (FTI)

\section{INTRODUCTION}

The concept of green concrete was first proposed by the Concrete Engineering Institute of Japan in 1990s. ${ }^{1}$ Until now, green concrete has been used in parking lots, roadside slopes, shoulder partitions and other projects in Japan, the United States and other countries. Eco-porous concrete is a kind of green concrete, mainly formed with coarse aggregate, water, cement and admixtures. After filling in the pores with soil, nutrients and water-retaining materials, eco-porous concrete can meet the growing needs of plants. Compared with ordinary concrete, eco-porous concrete has the function of planting, water purification, noise reduction and reducing the heat-island effect. $^{2-3}$

Due to the typical skeleton structure of porous concrete, environmental factors have an important influence on the service life of porous concrete, especially the freeze-thaw attacks. It is well known that the effect of materials (such as aggregates, cement, admixtures, etc.) on the freeze-thaw resistance should be explored, and the degradation characteristics of concrete should be stur died. ${ }^{4-8}$ Compared with permeable concrete, eco-porous concrete has a higher porosity and a larger pore size. There were few researches on the freeze-thaw resistance of eco-porous concrete. ${ }^{9-11}$ Considering the cost and ecological benefit, the industrial, waste, residue fly ash is usually added to concrete. ${ }^{12-13}$ Based on the above, fly ash was added to eco-porous concrete in the study. Accordingly, the freeze-thaw resistance and evaluation of porous concrete were researched. The results have an important guiding significance for the evaluation of frost resistance and preparation of eco-porous concrete.

\section{EXPERIMENTAL PART}

\subsection{Materials}

The P.O. 42.5 cement was selected. The performance indexes of the cement is shown in Table 1. There is only coarse aggregate, no fine aggregate. The II grade fly ash was used. 
Table1: Performance indexes of cement

\begin{tabular}{|c|c|c|c|c|c|c|c|c|}
\hline $\mathrm{SSA}^{2}$ & $\mathrm{SO}_{3}$ & Stabi- & IS & FS & $3 \mathrm{~d}$ FS & $3 \mathrm{dCS}$ & $28 \mathrm{dFS}$ & $28 \mathrm{dCS}$ \\
\cline { 1 - 6 } $\mathrm{m}^{2} / \mathrm{kg}$ & $\%$ & lity & $\mathrm{min}$ & $\mathrm{min}$ & $\mathrm{MPa}$ & $\mathrm{MPa}$ & $\mathrm{MPa}$ & $\mathrm{MPa}$ \\
\hline 354 & 2.4 & $\begin{array}{c}\text { qualifi } \\
\text { ed }\end{array}$ & 155 & 200 & 5.6 & 25.3 & 8.9 & 53.0 \\
\hline
\end{tabular}

Note: $\mathrm{SSA}=$ Specific surface area; IS = Initial setting; $3 \mathrm{dFS}=3 \mathrm{~d}$ flexural strength; $3 \mathrm{dCS}=3 \mathrm{~d}$ compressive strength; others similarly

\subsection{Mixture design}

The mix-design theory is similar to the filling theory of RCC. ${ }^{14}$ The design principles are: close packing of the coarse aggregate, the cementitious paste evenly distributed on the aggregate surface, a porosity of 20-30\% and the compressive strength after $28 \mathrm{~d}$ of 5-15 $\mathrm{MPa}$ as the control criteria. According to the findings of Y. P. Sheng and others, ${ }^{15-17}$ the primary mix proportion can be achieved.

Moreover, Y. Jing provided empirical data for the preparation of the vegetation-type eco-porous concrete. ${ }^{18}$ Based on the formula and empirical data, the test mix proportions are presented in Table 2 . The " $n$ value" represents $0,1,2,3,4,5$, respectively.

Table 2: Mix proportion of eco-porous concrete

\begin{tabular}{|c|c|c|c|c|c|}
\hline Number & FLC/\% & $\begin{array}{c}\text { Grain } \\
\text { size/mm }\end{array}$ & $\begin{array}{c}\text { Cement/ } \\
\mathrm{kg} / \mathrm{m}^{3}\end{array}$ & $\begin{array}{c}\text { Water/ } \\
\mathrm{kg} / \mathrm{m}^{3}\end{array}$ & $\begin{array}{c}\text { Water-bin } \\
\text { der ratio }\end{array}$ \\
\hline Fn & $10 \mathrm{n}$ & $19-26.5$ & 300 & 90 & 0.30 \\
\hline
\end{tabular}

Note $:$ FLC $=$ Fly ash content

\subsection{Specimen preparation}

Fly ash was used to replace cement in the amounts of $(0,10,20,30,40$ and 50) \%. Using the paste-coatinggravel method, cement, fly ash and $70 \%$ of water were mixed in a mechanical mixer for $1 \mathrm{~min}$, then the coarse aggregate was added, being mixed into the mixture for 1 min, and the remaining $30 \%$ of the water was added by mixing the mixture for another minute. The specimen size for the compression test was $(100 \times 100 \times 100) \mathrm{mm}$, and it was $(100 \times 100 \times 400) \mathrm{mm}$ for the transversefundamental-frequency test. After the mixing, a vibrating rod was used to ensure a good compaction and the specimens were demolded $24 \mathrm{~h}$ after being cast. Then, the specimens were cured in a standard curing room for $23 \mathrm{~d}$, and soaked in water $\left(20 \pm 2{ }^{\circ} \mathrm{C}\right)$ for another $4 \mathrm{~d}$. Meanwhile, the water level was higher than the top surface of the specimens by $20-30 \mathrm{~mm}$.

\section{EXPERIMENTAL METHOD}

In this study, the vacuum-sealing method, as specified in ASTM D7063, was adopted to determine the effective porosity of porous concrete. ${ }^{19}$ It is reported that this method can be effectively used for porous concrete due to its open-pore structure. ${ }^{20-21}$ Strength tests were conducted on porous-concrete specimens by following the testing procedures specified in GB/T 50081-2002. ${ }^{22}$ Triplicate cubic specimens with a side length of $100 \mathrm{~mm}$ were used for the testing. Compressive-strength tests were performed on the specimens after 28 curing $d$.

Cyclic freeze-thaw tests were conducted to determine the freeze-thaw resistance of the porous-concrete mixtures, mainly referring to the Chinese specification GB/T50082-2009, in which specimens were subjected to repeated freeze-thaw cycles. ${ }^{23}$ After $28 \mathrm{~d}$ of curing, we took the specimens out, wiping the surfaces with a cloth until there was no water on them. We numbered the specimens with the sides of $(100 \times 100 \times 400) \mathrm{mm}$, weighed the initial mass $\mathrm{M}_{0}$, measured the lateral fundamental frequency f0 and observed their appearance. We put the specimens with the dimensions of $(100 \times 100$ $\times 400) \mathrm{mm}$ and $(100 \times 100 \times 100) \mathrm{mm}$ into the box with wetting conditions; after 5 cycles of freezing and thawing, we measured the above criteria, until the RDME decreased to $60 \%$ or the mass-loss rate reached $5 \%$.

\section{RESULTS AND DISCUSSION}

\subsection{Uniaxial compressive strength}

The test results of the compressive strength obtained when the relative dynamic modulus of elasticity (RDME) of the eco-porous concrete was reduced to $60 \%$ are shown in Figure 1.

It can be clearly observed from Figure 1 that with an increase in the freeze-thaw cycle, the compressive strength decreased rapidly. The strength of the specimens without fly ash is larger than that of the specimens with fly ash. And with the increasing amount of fly ash, the compressive strength of the specimens significantly decreased.

The specimens damaged during the freeze-thaw attacks and compression tests can be seen in Figures 2 and 4 . The bonding sites of the aggregate were broken

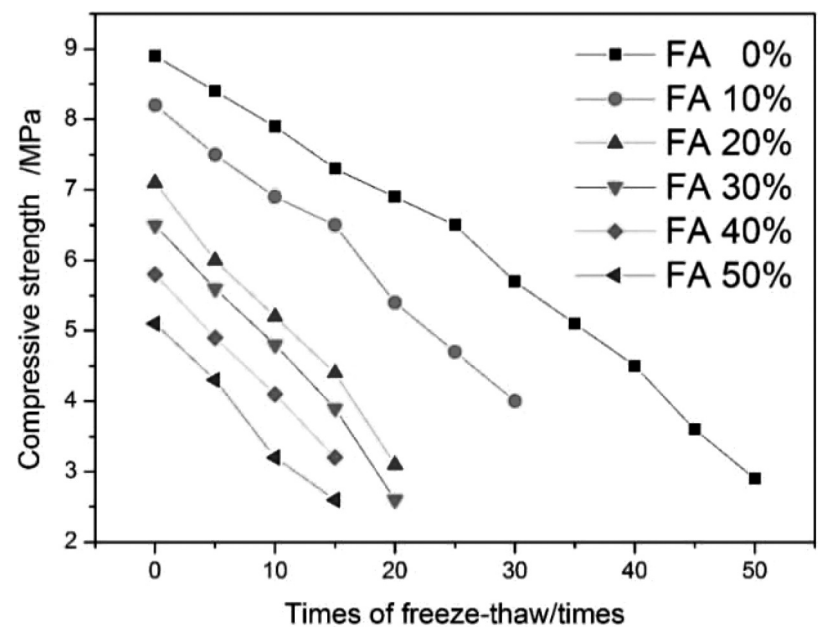

Figure 1: Relation between uniaxial compressive strengths and freeze-thaw times 
and cracks developed along the bond interface. This indicated that the contact areas were still weak. Therefore, the cementitious paste had to be modified to improve the strength of porous concrete. It is well known that cementitious paste gradually degrades under the expansion stress of ice, and the bond strength of cementitious paste also decreases. In addition, the high porosity of specimens provided the condition for water freezing, leading to an aggravated degeneration. On the other hand, the fly ash decreased the strength of the cementitious paste between aggregate particles. The content of fly ash also had to be controlled. Finally, with the increasing freezethaw cycles, the RDME of the specimens decreased to $60 \%$.

\subsection{Mass loss}

The mass-loss rate and the appearance of the specimens after the reduction of the RDME of eco-porous concrete to $60 \%$ are shown in Table 3 and Figure 4, respectively.

The mass-loss rate for the eco-porous concrete without fly ash was lower than for the other types of eco-porous concrete from Table 3. With the increasing amount of fly ash, the mass-loss rate increased, but it was still less than $5 \%$.

Table 3: Mass-loss rate of eco-porous concrete

\begin{tabular}{|c|c|c|c|c|c|c|}
\hline Fly-ash content (\%) & 0 & 10 & 20 & 30 & 40 & 50 \\
\hline Mass-loss rate (\%) & 0.06 & 0.09 & 0.11 & 0.12 & 0.16 & 0.19 \\
\hline
\end{tabular}

There were no cracks on the surfaces of the specimens, and only slight damage appeared, mainly on the surface, as shown in Figure 4. With the increasing cycles, individually spalled aggregate particles could be observed from Figure 2.

A lower water-binder ratio and the paste-coatinggravel method improved the strength of the cementitious paste and the interface between the aggregate particles. Then, the interfacial transition zone of eco-porous concrete was strengthened. Accordingly, the freeze-thaw resistance of eco-porous concrete significantly increased.

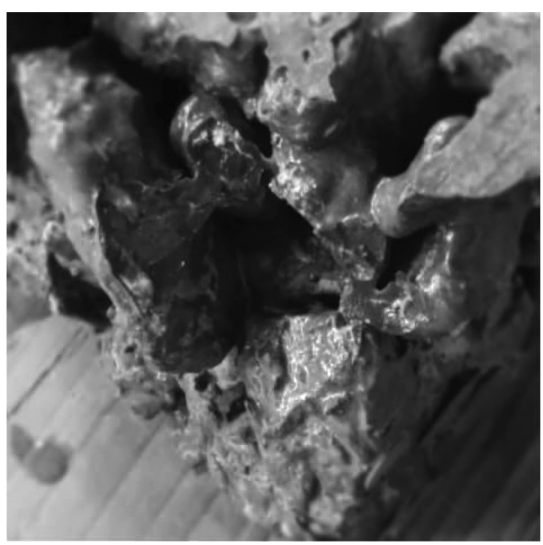

Figure 2: Freeze-thaw failure of a specimen

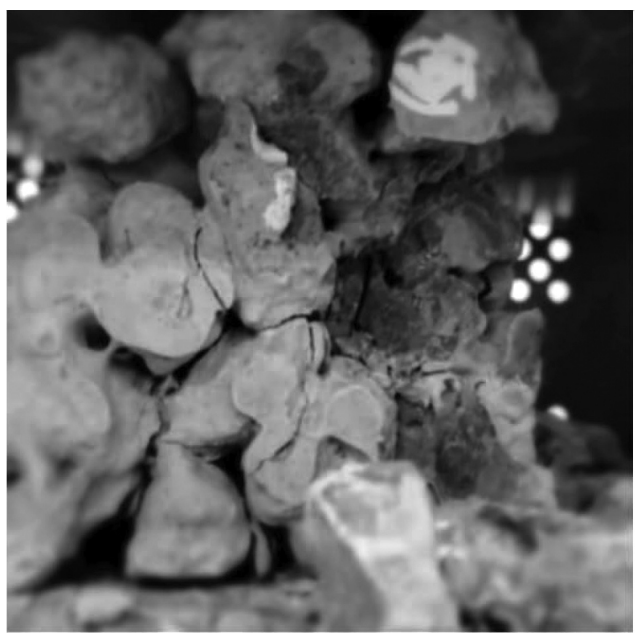

Figure 3: Compressive failure of a specimen

However, after the cement was replaced by fly ash, the activity, hydration degree and fluidity of the cementitious paste were reduced. Finally, the roughness and holes of the cementitious-paste surface increased. With the freeze-thaw attacks going on, the expansion stress from the holes caused the cementitious paste to peel off and fall off. Besides, with the increase in the fly ash, a small amount of particles appeared, but the mass-loss rate was still low.

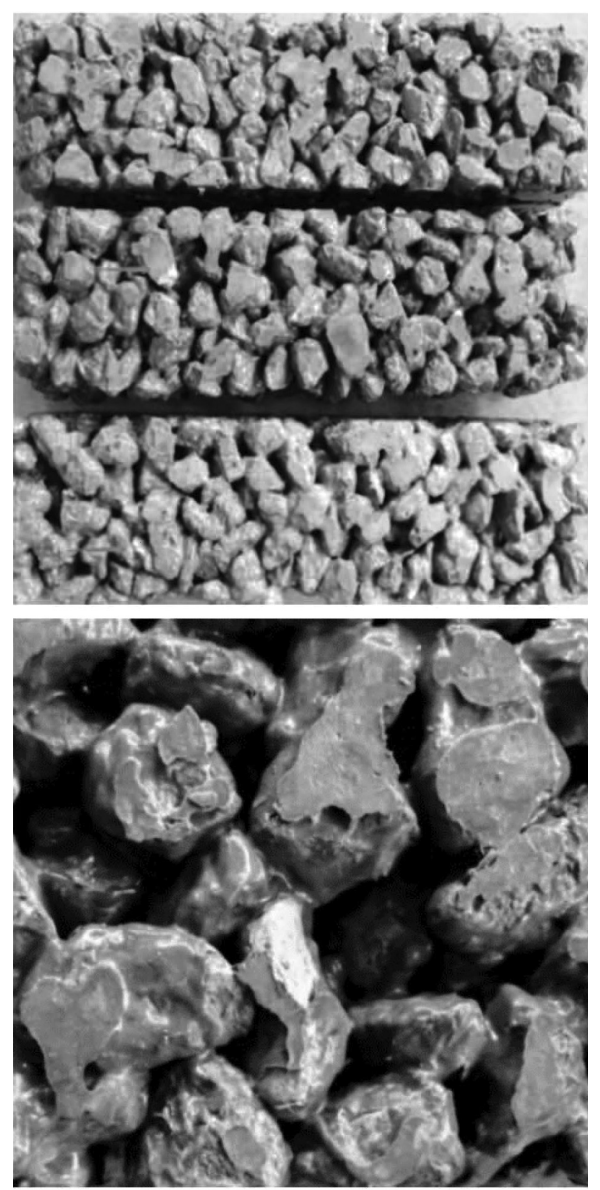

Figure 4: Appearance of the specimens 


\subsection{Relative dynamic modulus of elasticity (RDME)}

4.3.1 Analysis of relative dynamic modulus of elasticity $(R D M E)$

RDME curves for different fly-ash contents in eco-porous concrete are presented in Figure 5.

It can be clearly observed from Figure 5 that with an increase in the number of freeze-thaw cycles, the RDME decreased rapidly. The RDME of the specimens without fly ash is larger than that of the specimens with fly ash. And with the increasing amount of fly ash, the RDME of the specimens significantly decreased.

When the RDME was reduced to $60 \%$, the eco-porous-concrete specimens did not produce cracks that could be seen from Figure 4. As we can see, the variation trend of the RDME is similar to the compressive strength. Accordingly, the RDME values also depend on the durability of cementitious paste, the content of fly ash and freeze-thaw cycles. Nevertheless, the RDME value has an important role when evaluating the internal damage.

\subsubsection{Freeze-thaw damage index (FTI)}

The change in the relative dynamic modulus of elasticity (RDME) is the macroscopic form of microdamage (or internal damage). By establishing the relation between the RDME and freeze-thaw damage index, the damage degree of concrete during freeze-thaw attacks can be described. According to this, the formula is as follows:

$$
D_{F}=\left(E_{\mathrm{RI}}-E_{\mathrm{RF}}\right) / 0.4 E_{\mathrm{RI}}=2.5\left(1-E_{\mathrm{RF}}\right)
$$

where $D_{\mathrm{F}}$ is the freeze-thaw damage index, $0 \leq D_{\mathrm{F}} \leq 1$; $E_{\mathrm{RI}}$ is the initial RDME, its value is $1.0 ; E_{\mathrm{RF}}$ is the instantaneous RDME. Under the non-destruction condition, $E_{\mathrm{RI}}=E_{\mathrm{RF}}=1, D_{\mathrm{F}}=0$; under the theoretical limit state of freeze-thaw damage, $E_{\mathrm{RF}}=0.6 E_{\mathrm{RI}}$ and $D_{\mathrm{F}}=1$. When the RDME is included in formula (1), we find that the damage degree of specimens can be calculated using the freeze-thaw damage index. Furthermore, the closer $D_{\mathrm{F}}$ is to 1 , the greater the damage; the closer $D_{\mathrm{F}}$ is to 0 , the smaller the damage.

The larger the amount of fly ash, the lower the relative dynamic modulus of elasticity (RDME) of the porous concrete, as can be seen from Figure 5. In addition, when the fly-ash amounts were $40 \%$ and $50 \%$, the specimens were subjected to the freeze-thaw cycle five times. Therefore, the relation between the number of the freeze-thaw cycle and the freeze-thaw damage index was only studied when the fly ash amounts were $(0,10$, 20 and 30) \%. The fitting curve Equations (6), (7) and (8) are as follows:

$$
\begin{gathered}
0 \%: \mathrm{y}=-6 \times 10^{-7} x^{3}-8 \times 10^{-5} x^{2}-0.001 x+0.9969 \\
R^{2}=0.9983
\end{gathered}
$$

$10 \%: y=-0.0004 x^{2}-0.0092 x+1.0183$ $R^{2}=0.9821$

$20 \%: y=-0.0003 x^{2}-0.0205 x+1.019$ $R^{2}=0.9789$

$30 \%: y=-0.001 x^{2}-0.0257 x+1.0138$

$$
R^{2}=0.9824
$$

where $y$ is the RDME and $x$ is the number of freezethaw cycles. However, when the fly-ash content amounted to $30 \%$, the deviation between the calculated results and the experimental results was large. Therefore, the relation between the number of freezethaw cycles and the freeze-thaw index was not discussed when the fly-ash content exceeded $30 \%$. Next, we replaced the $E_{\mathrm{RF}}$ from Equation (1) with $y$ from Equations (2), (3) and (4), respectively. Then, new Equations (6), (7) and (8) were obtained for the fly-ash contents of $(0,10$ and 20$) \%$, as follows:

$$
\begin{gathered}
0 \%: D_{\mathrm{F}}=1.5 \times 10^{-6} x^{3}+2 \times 10^{-4} x^{2}+2.5 \times 10^{-3} x+ \\
+7.75 \times 10^{-3}
\end{gathered}
$$

$10 \%: D_{\mathrm{F}}=10^{-3} x^{2}+0.023 x-0.04575$

$20 \%: D_{\mathrm{F}}=7.5 \times 10^{-4} x^{2}+0.05125 x-0.0475$

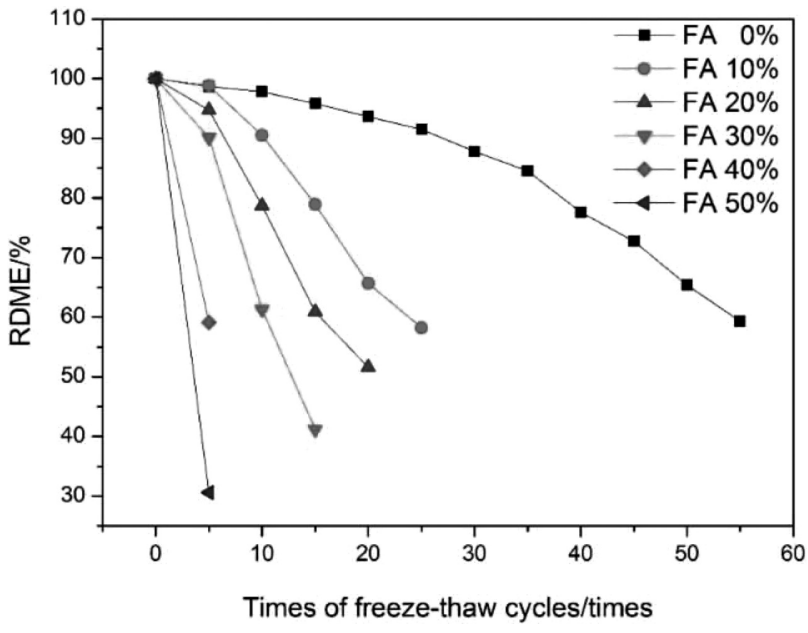

Figure 5: Relation between RDME and freeze-thaw cycles

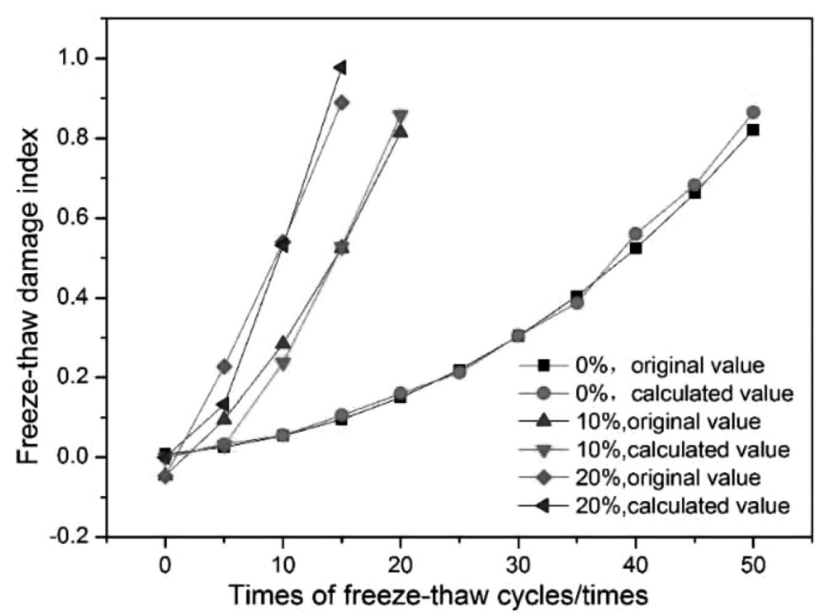

Figure 6: Relation between the calculated value and original value of freeze-thaw damage index 
The freeze-thaw damage index $D_{\mathrm{F}}$ increases with the increase in the number of freeze-thaw cycles from Equations (6), (7) and (8). Furthermore, the freeze-thaw damage degree for the specimens can be calculated by assuming the number of freeze-thaw cycles. The relation between the original value and calculated value of the freeze-thaw damage index of eco-porous concrete is shown in Figure 6.

It can be clearly seen that the deviation of the calculated value from the original value is small. That is to say, the freeze-thaw damage index can be used to describe the damage degree of eco-porous concrete during the freeze-thaw attacks. Moreover, the relation between the number of freeze-thaw cycles and freeze-thaw index can, not only be used to estimate the damage degree, but also to predict the number of freeze-thaw cycles that eco-porous concrete can withstand.

\section{CONCLUSIONS}

The fly-ash content has an important influence on the frost resistance of eco-porous concrete. In order to make eco-porous concrete with sufficient ecological benefits and a certain frost resistance, the fly-ash content should not exceed the total amount of cementitious paste, which is $30 \%$.

On the basis of the relative dynamic modulus of elasticity (RDME), the freeze-thaw damage index $D_{\mathrm{F}}$ is defined, and the freeze-thaw damage degree of ecoporous concrete can be estimated by calculating the value of $D_{\mathrm{F}}$. The relation between the freeze-thaw damage index $D_{\mathrm{F}}$ and the number of freeze-thaw cycles is obtained when fly-ash amounts account for 0,10 and $20 \%$. The freeze-thaw damage index $D_{\text {F }}$ can also be calculated by assuming the number of freeze-thaw cycles, through which we can obtain the freeze-thaw damage degree or evaluate the freeze-thaw resistance of eco-porous concrete.

When the relative dynamic modulus of elasticity (RDME) of eco-porous concrete decreased to $60 \%$, the number of freeze-thaw cycles was lower than that of compressive specimens. The relative dynamic modulus of elasticity (RDME) was selected to evaluate the frost resistance of eco-porous concrete. Therefore, the mass loss, appearance, and freeze-thaw damage can be used as the evaluation indexes for the frost resistance of ecoporous concrete.

\section{Acknowledgments}

The authors appreciate the support of the Hunan Province Science and Technology Department (Project Nos. 2013FJ2002, 14JJ4055) and the Central South University of Forestry and Technology (CX2017B41).

\section{REFERENCES}

${ }^{1}$ J. L. Wang, X. M. Wang, C. M. Feng, Y. N. Li, X. Zhao, Research progress on the planting eco-concrete, Bulletin of the Chinese Ceramic Society, 34 (2015) 7, 1915-1920, doi:10.16552/ j.cnki.issn1001-1625. 2015. 07.032

${ }^{2}$ L. Yan, Y. X. Bing, Z. K. Zhang, K. Cui, X. K. Pan, X. F. Yan, B. X. Li, S. G. Xie, Q. W. Guo, Influence of plantation on microbial community in porous concrete treating polluted surface water, International Biodeterioration \& Biodegradation, 117 (2017), 8-13, doi:10.101 6/j.ibiod.2016. 11.017

${ }^{3}$ K. H. Lee, K. H. Yang, Development of a neutral cementitious material to promote vegetation concrete, Construction and Building Materials, 127 (2016), 442-449, doi:10.1016/j.conbuildmat.2016. 10.032

${ }^{4}$ M. L. Zheng, S. F. Chen, B. G. Wang, Study on frost resistance property of porous concrete for road base, Concrete, (2007) 2, 31-33, doi:10.3969/j.issn.1002-3550.2007.02.010

${ }^{5}$ H. Wu, Z. Liu, B. B. Sun, J. Yin, Experimental investigation on freeze-thaw durability of Portland cement pervious concrete, Construction and Building Materials, 117 (2016), 63-71, doi:10.1016/j.conbuildmat.2016.04.130

${ }^{6}$ D. J. Xue, R. G. Liu, R. J. Xu, J. Yin, D. Liu, Z. M. Li, Experimental study on pervious eco-concrete in freezing-thawing circumstance, Bulletin of the Chinese Ceramic Society, 33 (2014) 6, 1480-1484, doi:10.16552/j.cnki.issn1001-1625.2014.06.065

${ }^{7}$ M. Gesoğlu, E. Güneyisi, G. Khoshnaw, S. İpek, Abrasion and freezing-thawing resistance of pervious concrete containing waste rubber, Construction \& Building Material, 73 (2014), 19-24, doi:10.1016/j.conbuildmat.2014.09.047

${ }^{8}$ T. Kevern, K. Wang, V. R. Schaefer, Effect of coarse aggregate on the freeze thaw durability of pervious concrete, Journal of Materials in Civil Engineering, 22 (2010) 5, 469-475, doi:10.1061/(ASCE)MT. 1943-5533.0000049

${ }^{9}$ T. Otomo, K. Otsuka, M. Kitatsuji, An Experimental Study on Freeze-Thaw Resistance and Plant Growth of Porous Concrete Containing Silica Fume and Fine Fibers, International Journal of Non-Linear Mechanics, 29 (1994) 2, 109-122, doi:10.3151/ crt1990.18.3_9

${ }^{10} \mathrm{X}$. B. Yan, Study on the preparation and properties of porous ecological concrete, Jinan, 2013, http://d.wanfangdata.com.cn/ Thesis/Y2364872

${ }^{11}$ J. S. Shi, Y. Geng, W. F. Zhang, Experiment study on endurance performances of the lean concrete, Sichuan Building Science, 41 (2015) 5, 43-46, doi:10.3969/j.issn.1008-1933.2015.05.010

${ }^{12}$ N. Puthipad, M. Ouchi, S. Rath, A. Attachaiyawuth, Enhanced entrainment of fine air bubbles in self-compacting concrete with high volume of fly ash using defoaming agent for improved entrained air stability and higher aggregate content, Construction and Building Materials, 144 (2017) 30, 1-12, doi:10.1016/j.conbuildmat.2017. 03.049

${ }^{13}$ A. K. Saha, P. K. Sarker, Sustainable use of ferronickel slag fine aggregate and fly ash in structural concrete: Mechanical properties and leaching study, Journal of Cleaner Production, 162 (2017), 438-448, doi:10.1016/j.jclepro.2017.06.035

${ }^{14}$ J. J. Zhang, History, current situation and trend of roller compacted concrete dam, Journal of North China Institute of water conservancy and hydropower, 21 (2000) 3, 1-7, doi:10.3969/j.issn.10025634.2000.03.001

${ }^{15}$ Y. P. Sheng, H. B. Li, W. Guan, Mix Design of Compaction-Free Porous Concrete Permeable Base, Advanced Materials Research, 368-373 (2012), 1416-1419, doi:10.4028/www.scientific.net/AMR. 368-373.1416

${ }^{16}$ L. M. Liang, Preparation, porous structure and Camouflage performance of porous ecological concrete, Nanjing, 2010, doi:10.7666/ d.y2046623

${ }^{17}$ J. Yin. H. Peng, Experimental Study on the Ecology and Green Concrete, Natural Science Journal of Xiangtan University, 37 (2015) 1, 37-42, doi:10.13715/j.cnki.nsjxu.2015.01.008 


\section{G. ZHANG et al.: INVESTIGATION OF THE FREEZE-THAW RESISTANCE OF ECO-POROUS CONCRETE ...}

${ }^{18} \mathrm{~J}$. Yang, Building materials and living environment, 1nd ed., Beijing, 2001, 209-238

${ }^{19}$ W. D. Martin, B. J. Putman, Comparison of methods for measuring porosity of porous paving mixtures, Construction \& Building Materials, 125 (2016), 299-305 doi:10.1016/j.conbuildmat.2016. 08.038

${ }^{20}$ B. Huang, H. Wu, X. Shu, E. G. Burdette, Laboratory evaluation of permeability and strength of polymer-modified pervious concrete, Constr. Build. 24 (2010) 5, 818-823, doi:10.1016/j.conbuildmat. 2009.10.025

${ }^{21}$ H. Wu, B. Huang, X. Shu, Q. Dong, Laboratory evaluation of abration resistance of Portland cement pervious concrete, J. Mater. Civil Eng., 23 (2011) 5, 697-702, doi:10.1061/(ASCE)MT.19435533.0000683

${ }^{22}$ H. B. Zhang, X. Q. Du, J. L. Kou, D. H. Yu, Research on compressive properties and water permeability of recycled aggregate pervious concrete, Journal of Experimental Mechanics, 32 (2017) 2, doi:10.7520/1001-4888-16-008

${ }^{23} \mathrm{~J}$. Q. Wang, Test research on the shrinkage and frost-resistance of recycled aggregate porous concrete, Industrial Construction, 46 (2016) 2, doi:10.13204/j.gyjz201602022 